\title{
Paralysis of occipitofrontalis in a borderline case of leprosy
}

\author{
BRAJENDRA MISHRA, G. N. MALAVIYA, * \\ A. GIRDHAR, S. HUSSAIN \& B. K. GIRDHAR \\ Central Jalma Institute for Leprosy (CJIL), (ICMR), Tajganj, \\ Agra, 282001 India
}

Accepted for publication 23 October 1992

\begin{abstract}
Summary A patient with neuritic leprosy developed borderline skin lesions. Later, another skin lesion developed on the left side of the forehead with clinical involvement of the supraorbital branch of the ophthalmic division of the trigeminal nerve. Simultaneously, paralysis of the occipitofrontalis and mild paresis of orbicularis oculi occurred.
\end{abstract}

\section{Introduction}

Leprosy is treated as a disease that affects peripheral nerves, the skin and the mucous membrane of the nose, mouth and eyes. The most common cranial nerve involvement leads to paralysis of orbicularis oculi and lagophthalmos. Diwan ${ }^{1}$ reported that there was an incidence of about $3 \%$ of this problem. Ishihara ${ }^{2}$ reported 4 cases of bulbar palsy. Loss of taste sensation due to involvement of the chorda tympani fibres of the facial nerve was reported by Sheskin ${ }^{3}$ and by Dharmendra \& Ramu. ${ }^{4}$ Later Malaviya \& Ramu ${ }^{5}$ reported a loss of taste sensation due to a combined involvement of facial, lingual and glossopharyngeal nerves.

\section{Case report}

RJ, a 37-year-old Hindu male, came to the Central Jalma Institute of Leprosy, Agra, complaining of a loss of sensation of the anterolateral aspect of the lower left leg of 6 weeks' duration. He had not received any treatment and was not aware of any relatives and friends suffering with similar problems.

* Correspondence: c/o Dr G. N. Mishra 


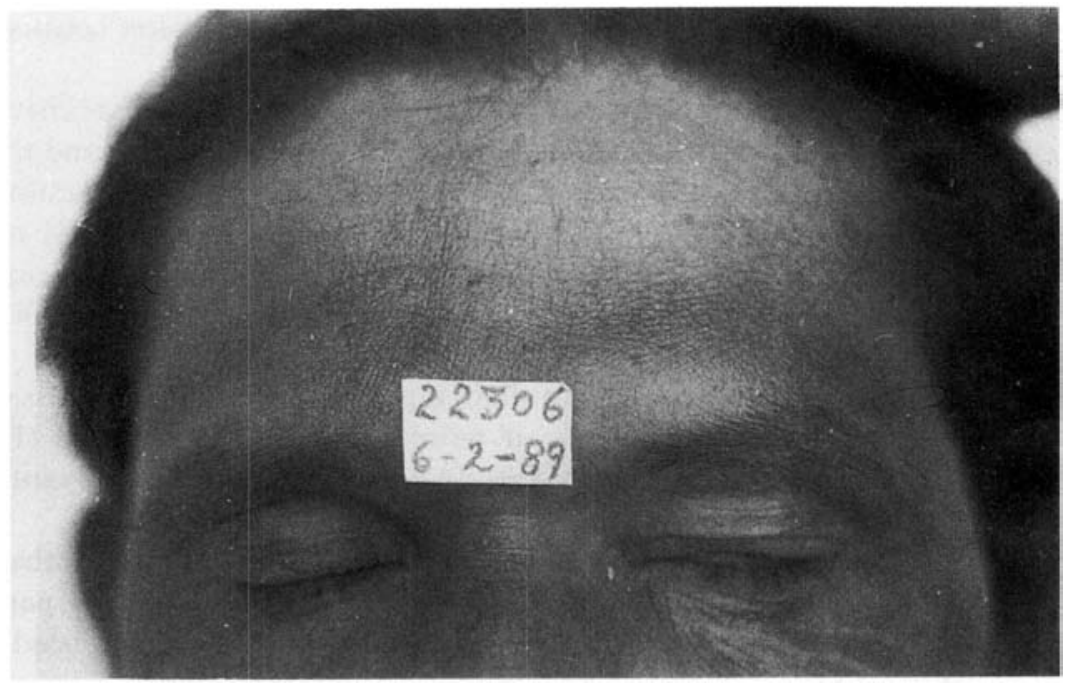

Figure 1. Hypopigmented lesion on the left side of the forehead and incomplete closure of the left eyelid due to lagophthalmos.

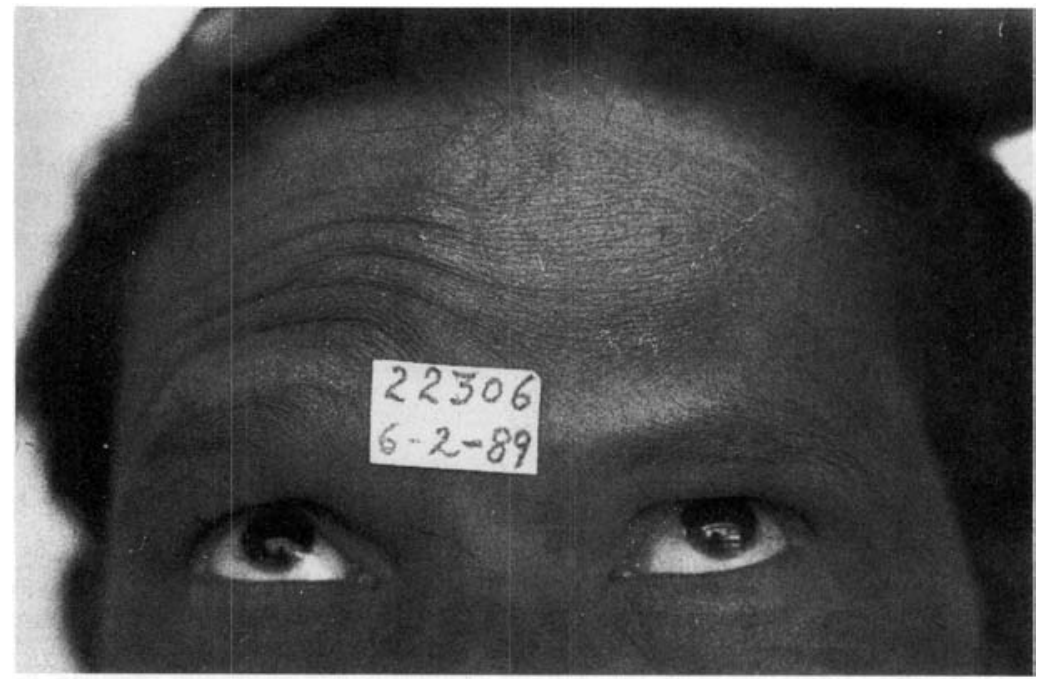

Figure 2. A well-demarcated lesion with total absence of wrinkling on the left-side of the forehead due to paralysis of the frontal belly of the occipitofrontalis.

On examination, there was anaesthesia on the anterolateral aspect of the lower twothirds of the left leg. The left superficial peroneal nerve was thickened. The slit-skin smear on examination was negative but the Dharmendra Lepromin test was weakly positive for early reaction. A diagnosis of neuritic leprosy was made.

The patient received standard antileprosy therapy consisting of rifampicin $600 \mathrm{mg}$ once a month and dapsone $100 \mathrm{mg}$ daily for a month.

After treatment for 10 months, he noticed a hypopigmented erythematous patch where he first had anaesthesia. This was diagnosed as a BT lesion. As there was no change 
in the bacteriological status the treatment was continued and the lesion became inactive after 1 year.

After the disease had been considered inactive at a subsequent visit a slight hypopigmentation was found on the left side of the forehead (Figure 1) and the patient complained of a tingling sensation whenever he pressed this area. On examination the supraorbital branch of the left ophthalmic division of the left trigeminal nerve was palpable and firm pressure evoked tingling. Within 1 month this skin lesion became more demarcated. At this stage steroids were added for symptomatic relief and $450 \mathrm{mg}$ of rifampicin were given daily for a fortnight.

After 6 months, the patient developed a slight lagophthalmos and paralysis of the left occipitofrontalis muscle resulting in loss of wrinkling over the forehead (Figure 2). Steroids and Berin were presented in full doses. In addition to this, the relevant exercises were explained and he was asked to wear protective glasses.

Antileprosy therapy was continued as before. The disease became inactive after 12 months of therapy, but the anesthesia and lagophthalmos along with paralysis of occipitofrontalis and resultant loss of wrinkling on the forehead still persisted.

\section{Discussion}

In the last few years workers have reported a change from neuritic to borderline leprosy. ${ }^{6-9}$ In this patient both types occurred together. Damage to the zygomatic branch of the facial nerve in the region of the zygomatic osseofibrous tunnel results in lagophthalmos. The temporal branches supplying to the frontal belly of the occipitofrontalis are also parallel to the zygomatic branch. The damage mechanism is probably similar.

The combination of paralysis of the occipitofrontalis and neuritis in the supraorbital branch of the trigeminal nerve is an unusual feature.

\section{References}

1 Diwan VS. A survey of deformities in leprosy (with special reference to face). Lepr Rev, 1962; 33: 255-264.

2 Ishihara S. Bulbar palsy appearing in leprosy patients. La Le pro, 1967; 36: 199 (Japanese: English summary).

3 Sheskin J, Even Tov Y. El Sentido del gusto en el mal de Hansen Lepro gia 1974; 19: 3 (Spanish: English summary).

4 Dharmendra, Ramu. Leprosy, vol. 1, p. 311. Kothari Medical Publishing-House, Bombay, p. 311 , 1979.

5 Malaviya GN, Ramu G. Loss of taste sensation over the tongue in leprous facial palsy-A case report. Lepr India, 1981; 53(4): 656-659.

6 Noordeen SK. Epidemiology of polyneuritic type of leprosy. Lepr India, 1972; Vol. XLIV. No. 2, pp. 90-96.

7 Chacko GJG. Evolution of pathological lesions in leprosy patients and their immunological significance. Proceedings of Indo-U.K. Symposium on leprosy (1986), pp. 82-89, published at the Central Jalma Institute for Leprosy.

8 Shenoi, SD, Padhee A. Poly-neuritic leprosy changing in borderline tuberculoid (BT). Ind Jr Lepr, 1990; 62: 363-364.

9 Talwar S, Jha PK, Tiwari VD. Neuritic leprosy epidemiology and therapeutic responsiveness. (Abstract) XVII Biennial Conference and the Workshop of Indian Association of leprologists. 1992. Abstract of Scientific Papers (F.C.38), p. 36. 


\title{
Paralysie de l'occipito-frontal dans un cas de l'epre borderline
}

\author{
B. Mishra, G. N. Malaviya, A. Girdhar, S. Hussain et B. K. Girdhar
}

Résumé Un patient atteint de lèpre névrotique a présenté des lésions cutanées borderline. Plus tard, une autre lésion cutanée s'est developpée sur le côté gauche du front avec atteinte de la branche supra-orbitale de la division ophtamique du nerf trijumeau. Simultanément, la paralysie de l'occipito frontalis et une faible parésie de l'orbicularis oculi ont été observées.

\section{Parálisis del occipucio frontal en un caso de lepra incierta}

B. Mishra, G. N. Malaviya, A. Girdhar, S. Hussain y B. K. Girdhar

Resumen Un paciente con lepra neurítica desarrolló lesiones inciertas de la piel. Más tarde, otra lesión de la piel desarrolló e n el lado izquierdo de la frente con implicaciones clínicas de la rama supraorbital de la división oftálmica del nervio trigeminal. Simultáneamente, occurrió una parálisis del occipucio frontal y una paresia del orbicular ocular. 